УДК 336.1

В. А. Бубнов

Иркутский государственный университет путей сообщения, г. Иркутск, Российская Федерация

\title{
ПРОГНОЗ ЭКОНОМИЧЕСКОГО РОСТА В РЕЗУ ЛЬТАТЕ ПРИМЕНЕНИЯ ГОСУДАРСТВЕННОГО ЦЕЛЕВОГО ПРОЕКТНОГО ФИНАНСИРОВАНИЯ НА ПРИМЕРЕ БАЙКАЛЬСКОГО РЕГИОНА
}

\begin{abstract}
АНнОтАЦия. Проблема прогнозирования экономического роста в результате государственного финансирования в современных экономических условиях, характеризующихся снижением объема государственных финансовых ресурсов, повышением эффективности финансирования региональной экономики, относится к перечню задач, стоящих перед российским обществом. Действующая многоканальная система финансирования не учитывает особенности социально-экономического развития конкретных субъектов Федерации и, как следствие, не способствует приросту валового регионального продукта, поэтому предлагается использовать целевой проектный подход при осуществлении государственного финансирования. Апробация предлагаемого подхода осуществлена на примере субъектов Федерации, входящих в Байкальский регион. В статье рассматриваются направления государственного финансирования для достижения целевого индикатора - среднероссийского показателя валового регионального продукта на душу населения, на примере Иркутской области, Забайкальского края и Республики Бурятия. По каждому из регионов предложен алгоритм действий, что позволяет применить деятельностный подход $\kappa$ государственному финансированию на практике.

кЛЮчЕВЫЕ СЛОВА. Финансирование; регион-квазикорпорация; регион-квазигосударство; региональный бюджет; прирост валового-регионального продукта.

ФИНАНСИРОВАНИЕ. Государственное задание № 26.1348.2014/К на выполнение научно-исследовательских работ в сфере научной деятельности в рамках проектной части, проект № 1348 «Влияние теневого сектора экономики на качество жизни населения в России и Украине: сравнительный анализ» (номер госрегистрации в ФГАНУ ЦИТИС 114091140015).
\end{abstract}

ИНФОРМАЦИЯ О СТАТЬЕ. Дата поступления 11 августа 2016 г.; дата принятия к печати 2 сентября 2016 г.; дата онлайн-размещения 30 сентября 2016 г.

A. A. Bubnov

Irkutsk State Railway Engineering University, Irkutsk, Russian Federation

\section{FORECASTING OF ECONOMIC GROWTH AS A RESULT OF USING GOVERNMENTAL TARGET-BASED PROJECT FINANCING IN TERMS OF BAIKAL REGION}

\begin{abstract}
The problem of forecasting of economic growth as a result of governmental financing in the current economic environment, characterized by decrease in volumes of the governmental financial resources, by increase in efficiency of the regional economy financing, refers to the list of challenges facing the Russian society. The current multi-channel funding system does not take into account the peculiarities of socio-economic development of specific subjects of the Federation, and, therefore, it does not contribute to increasing the gross regional product, so the article proposes to use a target project-based approach in implementing the governmental financing. Practical approval of the proposed approach is carried out through the example of the Federation subjects, the members of Baikal Region. The article considers directions of governmental financing for achieving the target indicator - an average Russian index of the per capita gross regional product through the example of Irkutsk Oblast, region, Zabaikalye Territory and Republic of Buryatia. Each of the regions is offered an algorithm of actions, which allows to apply an activity-based approach to governmental financing in practice.
\end{abstract}

(C) В. А. Бубнов, 2016

\section{Baikal Research Journal}


KEYWORDS. Financing; region-quasicorporation; region-quasistate; regional budge; increments of GRP.

FINANCING. This article was written with the financial support from State task № 26.1348.2014/K for research, Project № 1348 «Influence of shadow economy on the quality of life of the population in Russia and Ukraine: comparative analysis» (number of state registration at the Federal Center of Information Technology and Systems 114091140015).

ARTICLE INFO. Received August 11, 2016; accepted September 2, 2016; available online September 30, 2016.

Мировой экономический кризис 2008 г. и его осмысление привели и ученых, и политиков к изменению представлений о роли государства в экономическом развитии. Кризис показал, что государство есть не только высший политический институт общества, но и тот институт, который несет ответственность за состояние экономической системы. В экономиках всех стран, попавших в полосу кризиса, именно государство пришло на помощь и финансовому сектору, и реальной экономике.

Современная экономическая ситуация в России также требует новых подходов к изучению роли государства в экономических процессах и поиску инструментов, позволяющих ему эффективно влиять на экономическое развитие. Одним из таких инструментов является государственное финансирование.

Решить задачу стимулирования комплексного развития регионов, не распыляя ограниченные финансовые ресурсы государства, позволит внедрение государственного целевого проектного финансирования. Переход к проектным принципам государственного финансирования на уровне субъектов Федерации требует тщательного научного обоснования, в том числе путем составления прогноза экономического роста в результате его реализации.

В ходе научного исследования была разработана факторная модель, которая может применяться не только для оценки существующей ситуации, но и для построения прогнозов. Возникает необходимость осуществить проверку применимости разработанных предложений на примере ряда регионов. Проведем апробацию предложенной модели на примере субъектов Федерации, входящих в Байкальский регион. Развитие Байкальского региона, включающего в себя Иркутскую область, Республику Бурятия и Забайкальского края, имеет ряд проблем, рассмотренных нами ранее в статье «Проблемы формирования Байкальского региона» [1], которые тормозят данный процесс.

Разработка программ развития, а также повышения доходных потенциалов субъектов Федерации [2] наталкивается на отсутствие у них собственных финансовых ресурсов. Фактически, по мнению В. В. Иванова, «существует значительное рассогласование объема задач регионального уровня с источниками и направленностью финансовых ресурсов» [3]. Следовательно, дополнительные финансовые ресурсы, получаемые в результате государственного целевого проектного финансирования в конкретном субъекте Федерации, должны оставаться в нем для воспроизводственного финансирования. Необходимо законодательное закрепление такого финансового механизма в Бюджетном кодексе РФ, что позволит построить сбалансированную и устойчивую региональную финансовую систему. Несмотря на отсутствие этого в настоящее время, предлагаемое нами государственное целевое проектное финансирование по направлениям, способствующим экономическому росту, предполагает, что часть прироста валового регионального продукта (ВРП) будет использоваться для финансирования проекта регионального развития.

В соответствии с проведенным в анализом Республика Бурятия является квазикорпорацией, а Иркутская область и Забайкальский край - квазигосударствами. Несовпадение типов регионов с позицией финансирования не позволяет сформиро-

\section{Baikal Research Journal}

электронный научный журнал Байкальского государственного университета 
вать единый подход к государственному целевому проектному финансированию. Для построения прогноза необходимо внести корректировку в разработанную модель, исходя из доли ВРП, зачисляемой в виде налоговых поступлений в консолидированный региональный бюджет. Для осуществления анализа используем данные (табл. 1) о ВРП субъектов Сибирского федерального округа (СФО) и о поступлении налогов в консолидированный региональный бюджет субъектов СФО за период 2008-2013 гг. (табл. 2).

Таблица 1

Валовой региональный продукт по субъектам Сибирского федерального округа в 2008-2013 г2. (в текущих ценах), млн р.

\begin{tabular}{|l|r|r|r|r|r|r|}
\hline \multicolumn{1}{|c|}{ Субъект } & \multicolumn{1}{c|}{2008} & \multicolumn{1}{c|}{2009} & \multicolumn{1}{c|}{2010} & \multicolumn{1}{c|}{2011} & \multicolumn{1}{c|}{2012} & \multicolumn{1}{c|}{2013} \\
\hline $\begin{array}{l}\text { Сибирский федераль- } \\
\text { ный округ }\end{array}$ & 344209,8 & 3391088,1 & 4131394,4 & 4802933,8 & 5186808,5 & 5535449,5 \\
\hline Республика Алтай & 18701,0 & 19911,6 & 22393,7 & 26380,8 & 30444,6 & 33089,9 \\
\hline Республика Бурятия & 124738,5 & 121187,7 & 133525,6 & 153624,1 & 164737,8 & 177692,0 \\
\hline Республика Тыва & 23870,5 & 26921,9 & 30772,8 & 33398,9 & 37369,1 & 41749,2 \\
\hline Республика Хакасия & 72308,8 & 81019,9 & 96039,8 & 113088,1 & 130638,5 & 143534,2 \\
\hline Алтайский край & 259343,1 & 265613,3 & 302900,7 & 332117,8 & 368995,2 & 410824,6 \\
\hline Забайкальский край & 140302,0 & 148587,9 & 166742,5 & 203869,0 & 223968,8 & 229782,0 \\
\hline Красноярский край & 737950,5 & 749194,8 & 1055525,0 & 1170827,3 & 1183228,0 & 1256674,5 \\
\hline Иркутская область & 438852,4 & 458774,9 & 546141,0 & 634561,4 & 737971,6 & 796587,0 \\
\hline Кемеровская область & 575901,9 & 512408,0 & 625914,9 & 751198,4 & 718320,4 & 668311,9 \\
\hline $\begin{array}{l}\text { Новосибирская об- } \\
\text { ласть }\end{array}$ & 453574,6 & 425400,2 & 484141,3 & 598563,5 & 728154,0 & 821415,4 \\
\hline Омская область & 347760,3 & 336259,6 & 382620,4 & 451418,8 & 491507,6 & 553242,7 \\
\hline Томская область & 248906,2 & 245808,3 & 284676,7 & 333885,7 & 371472,9 & 402546,1 \\
\hline
\end{tabular}

Составлено по данным: Регионы России. Социально-экономические показатели [Электронный pecypc]. URL : http://www.gks.ru/wps/ wcm/connect/rosstat_main/rosstat/ru/statistics/publications/ catalog/doc_1138623506156.

Таблица 2

Поступление налогов в консолидированный региональный бюджет субъектов Сибирского федерального округа в 2008-2013 г2., млн р.

\begin{tabular}{|c|c|c|c|c|c|c|}
\hline Субъект Федерации & 2008 & 2009 & 2010 & 2011 & 2012 & 2013 \\
\hline $\begin{array}{l}\text { Сибирский федеральный } \\
\text { округ }\end{array}$ & 573819,7 & 717708,9 & 793833,2 & 887995,9 & 914356,9 & 923839,9 \\
\hline Республика Алтай & 8990,4 & 13455,2 & 13316,8 & 15114,6 & 13956,7 & 15757,5 \\
\hline Республика Бурятия & 2816,7 & 40589,6 & 39198,1 & 44754,3 & 47272,4 & 52001,5 \\
\hline Республика Тыва & 10022,9 & 15311,9 & 15246,6 & 16706,6 & 21225,6 & 20974,3 \\
\hline Республика Хакасия & 12056,3 & 17330,3 & 18347,9 & 21221,6 & 22845,3 & 22350,8 \\
\hline Алтайский край & 47086,7 & 65513,4 & 72375,8 & 81204,0 & 82275,0 & 87556,6 \\
\hline Забайкальский край & 24833,6 & 40806,9 & 43739,9 & 46358,5 & 47619,1 & 52399,3 \\
\hline Красноярский край & 139598,6 & 155429,7 & 178352,6 & 188773,6 & 176562,7 & 175944,5 \\
\hline Иркутская область & 65743,4 & 88586,6 & 98500,7 & 113112,0 & 124250,9 & 120305,3 \\
\hline Кемеровская область & 84258,5 & 100371,8 & 113379,2 & 128335,8 & 120925,7 & 113720,5 \\
\hline Новосибирская область & 72435,3 & 87021,4 & 100301,9 & 112628,9 & 129040,9 & 130244,9 \\
\hline Омская область & 51215,0 & 53936,1 & 58097,8 & 67352,3 & 75802,9 & 78900,3 \\
\hline Томская область & 29412,0 & 39356 & 42975,9 & 52433,7 & 52579,7 & 53684,4 \\
\hline
\end{tabular}

\section{Baikal Research Journal}


Результаты расчета (табл. 3) представлены в виде средневзвешенной доли за анализируемый период. Как видно (рис. 1), только в двух регионах данный показатель превышает 50 \% - Республика Тыва и Республика Алтай.

Доля валового внутреннего продукта, зачисляемая

Таблица 3

в консолидированный региональный бюджет в виде налогов в 2008-2013 г2., \%

\begin{tabular}{|l|r|r|r|r|r|r|r|}
\hline \multicolumn{1}{|c|}{ Субъект Федерации } & 2008 & 2009 & 2010 & 2011 & 2012 & 2013 & $\begin{array}{c}\text { Средневзве- } \\
\text { шенный } \\
\text { показатель }\end{array}$ \\
\hline Сибирский федеральный округ & 0,167 & 0,212 & 0,192 & 0,185 & 0,176 & 0,167 & 0,183 \\
\hline Республика Алтай & 0,481 & 0,676 & 0,595 & 0,573 & 0,458 & 0,476 & 0,543 \\
\hline Республика Бурятия & 0,226 & 0,335 & 0,294 & 0,291 & 0,287 & 0,293 & 0,288 \\
\hline Республика Тыва & 0,420 & 0,569 & 0,495 & 0,500 & 0,568 & 0,502 & 0,509 \\
\hline Республика Хакасия & 0,167 & 0,214 & 0,191 & 0,188 & 0,175 & 0,156 & 0,182 \\
\hline Алтайский край & 0,182 & 0,247 & 0,239 & 0,245 & 0,223 & 0,213 & 0,225 \\
\hline Забайкальский край & 0,177 & 0,275 & 0,262 & 0,227 & 0,213 & 0,228 & 0,230 \\
\hline Красноярский край & 0,189 & 0,207 & 0,169 & 0,161 & 0,149 & 0,140 & 0,169 \\
\hline Иркутская область & 0,150 & 0,193 & 0,180 & 0,178 & 0,168 & 0,151 & 0,170 \\
\hline Кемеровская область & 0,146 & 0,196 & 0,181 & 0,171 & 0,168 & 0,170 & 0,172 \\
\hline Новосибирская область & 0,160 & 0,205 & 0,207 & 0,188 & 0,177 & 0,159 & 0,183 \\
\hline Омская область & 0,147 & 0,160 & 0,152 & 0,149 & 0,154 & 0,143 & 0,151 \\
\hline Томская область & 0,118 & 0,160 & 0,151 & 0,157 & 0,142 & 0,133 & 0,144 \\
\hline
\end{tabular}

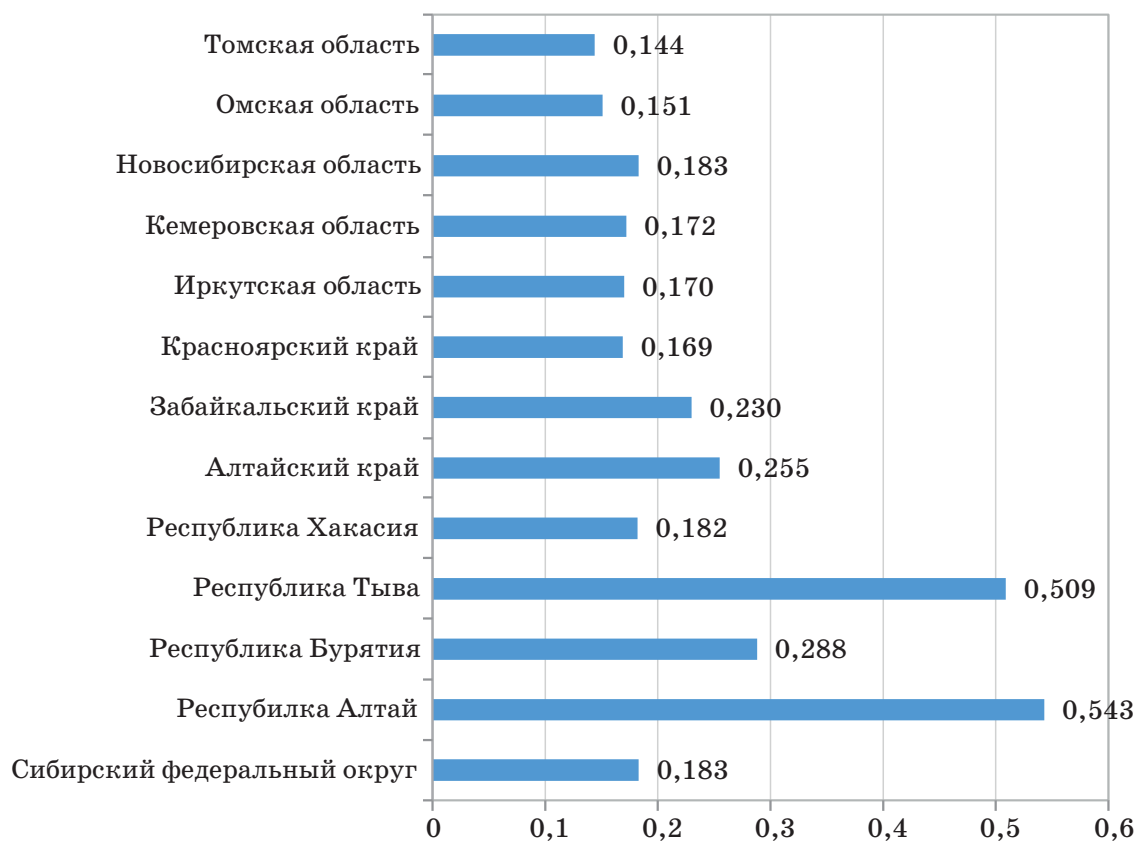

Рис. 1. Средневзвешенная доля валового регионального продукта, администрируемая через консолидированный региональный бюджет субъектов Сибирского федерального округа, \%

Низкие показатели доли ВРП, зачисляемой в виде налогов в консолидированный региональный бюджет, не позволяют сформировать заинтересованность региональных органов власти в реализации проектов. По мнению В. В. Иванова, «на-

\section{Baikal Research Journal}


личие альтернативного дополнительного источника финансирования позволяет... эффективнее реализовывать новые региональные и муниципальные проекты» [4].

Далее рассмотрим субъекты Федерации, входящие в Байкальский регион. Средневзвешенная доля средств, остающихся в распоряжении субъектов Федерации, составляет:

- Республика Бурятия - 0,288 или 28,8 \% ;

- Забайкальский край - 0,23 или $23 \%$;

- Иркутская область - 0,17 или $17 \%$.

Считаем важным отметить, что существуют серьезные расхождения данного показателя по рассматриваемым регионам. Данные показатели необходимо использовать для определения объема денежных средств, поступающих в распоряжение региона в результате увеличения ВРП в ходе осуществления государственного целевого проектного финансирования.

Разберем результаты применения модели для Байкальского региона (табл. 4). Следует учитывать низкий уровень критерия детерминации по Забайкальскому краю.

Результаты модели по Байкальскому региону за 2000-2014 г2.

\begin{tabular}{|l|c|c|}
\hline \multicolumn{1}{|c|}{ Регион } & Модель & $\begin{array}{c}\text { Критерий } \\
\text { детерминации }\end{array}$ \\
\hline Республика Бурятия & $y=-1,01 \mathrm{e}_{5}+4,17 x_{2}+1,66 \mathrm{e} 3 x_{6}-0,0552 x_{7}+6,13 \mathrm{e} 6 x_{10}$ & $R^{2}=0,909$ \\
\hline Забайкальский край & $y=-9,83 \mathrm{e}_{4}+25,6 x_{1}-2,26 x_{2}-16,7 x_{3}$ & $R^{2}=0,720$ \\
\hline Иркутская область & $y=-72031,3+3,58133 x_{2}+0,28136 x_{7}+$ & $R^{2}=0,999$ \\
& $+16160,7 x_{8}-12941,2 x_{9}$ & \\
\hline
\end{tabular}

Составлено на основе факторной модели.

Выделим факторы, влияющие на прирост ВРП по рассматриваемым субъектам Федерации (табл. 5). Отметим, что с позиций государственного финансирования данные факторы различаются по возможности воздействия на них, поэтому следует отдать предпочтения расходам регионального бюджета и расходам государственных внебюджетных фондов, т. е. тем факторам, которые можно отнести к «собственным финансовым ресурсам для их реализации» [5], что не повлечет увеличения расходов по привлечению заемных средств.

Таблица 5

Факторы, влияющие на валовой внутренний продукт по Байкальсколу региону

\begin{tabular}{|c|l|l|}
\hline $\begin{array}{c}\text { Обозна- } \\
\text { чение }\end{array}$ & \multicolumn{1}{|c|}{ Параметр } & $\begin{array}{l}\text { Форма организации } \\
\text { денежных отношений }\end{array}$ \\
\hline$x_{1}$ & $\begin{array}{l}\text { Расходы регионального бюджета на душу населения в год, } \\
\text { р./чел. }\end{array}$ & $\begin{array}{l}\text { Государственные } \\
\text { финансы }\end{array}$ \\
\hline$x_{2}$ & $\begin{array}{l}\text { Расходы государственных внебюджетных фондов на душу } \\
\text { населения в год, р./чел. }\end{array}$ & \\
\hline$x_{10}$ & Доля госслужащих, \% & $\begin{array}{l}\text { Корпоративные } \\
\text { финансы }\end{array}$ \\
\hline$x_{3}$ & Инвестиции в основной капитал на душу населения в год, p. & Финансы домашних \\
\cline { 1 - 2 } & Отправление грузов железнодорожным транспортом, млн т & хозяйств \\
\hline$x_{7}$ & Среднедушевые доходы в год, р. /чел. & \\
\hline$x_{8}$ & Уровень занятости, \% в среднем за год & \\
\hline$x_{9}$ & Уровень экономической активности, \% в среднем за год & \\
\hline
\end{tabular}

Составлено на основе факторной модели.

Факторами, на которые государство способно оказать влияние с минимальными издержками, - это $x_{1}$ и $x_{2}$. Рассмотрим их тренды за 2000-2014 гг. применительно к субъектам Байкальского региона и спрогнозируем результаты их на 2015-2017 гг.

\section{Baikal Research Journal}

электронный научный журнал Байкальского государственного университета 
Первоначально проанализируем показатели по Республике Бурятия (рис. 2). Тренды имеют положительную динамику за 2000-2014 гг., следовательно, прогноз на 2015-2017 гг. достаточно достоверен. Оба тренда можно использовать в качестве источников государственного целевого проектного финансирования с учетом существующих «региональных бюджетных рисков» [6].

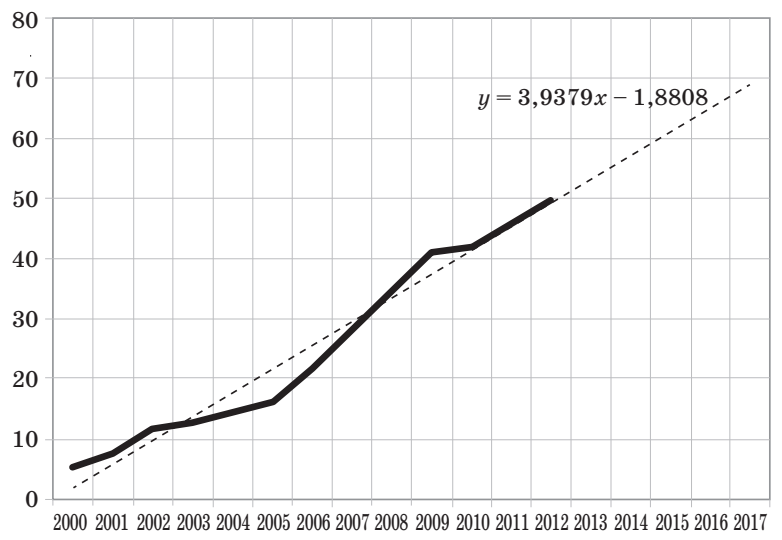

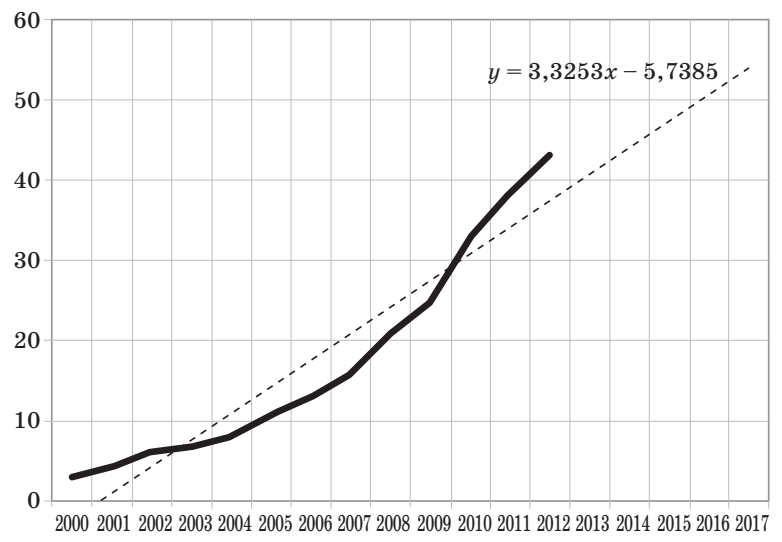

б

Рис. 2. Тренды расходов регионального бюджета (a) и государственных внебюджетных фондов (б) на душу населения в Республике Бурятия в 2000-2017 г2., тыс. p./чел.

(Составлено на основе факторной модели)

Тренды Забайкальского края (рис. 3) имеют положительную динамику за 2000 2014 гг., следовательно, прогноз на 2015-2017 гг. достаточно достоверен. В данном случае следует учесть, что расходы государственных внебюджетных фондов имеют лучший тренд, но при этом они оказывают отрицательное воздействие на экономический рост. Для нивелирования данного фактора важно «обеспечить представление о партнерстве» [7] как ключевого условия устойчивого экономического роста. Создание общей среды, комфортной для социума рассматриваемого субъекта Федерации, будет способствовать приросту ВРП.

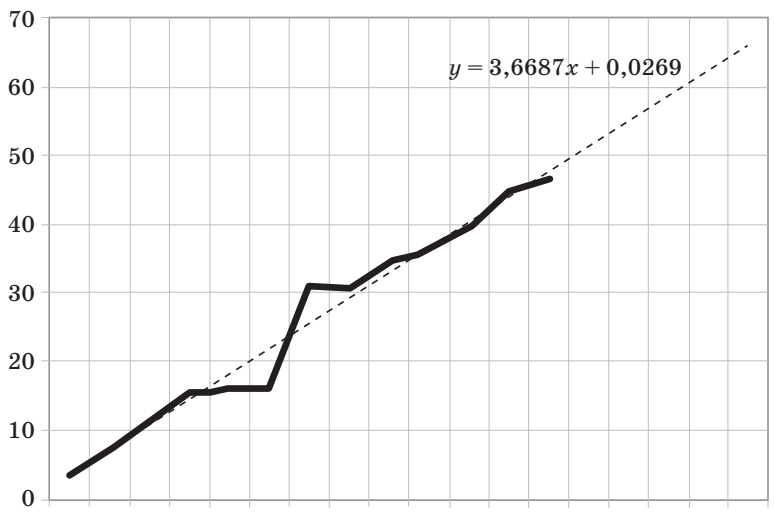

200020012002200320042005200620072008200920102011201220132014201520162017

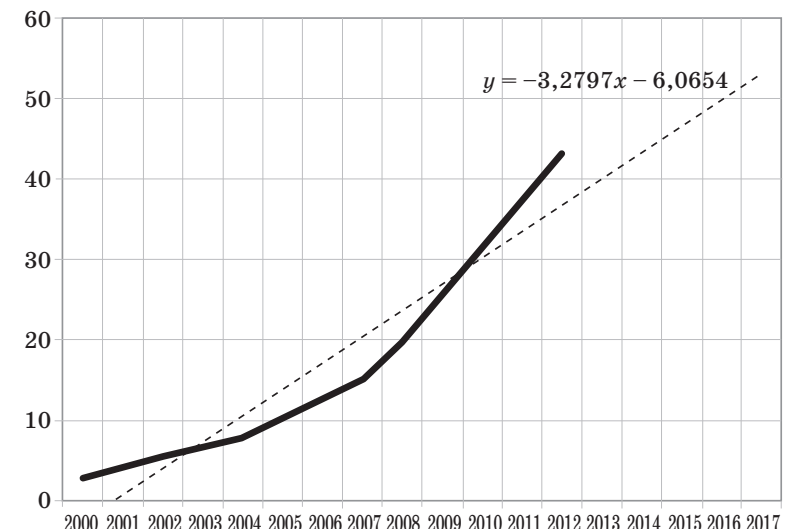

б

Рис. З. Тренды расходов регионального бюджета (а) и государственных внебюджетных фондов (б) на душу населения в Забайкальском крае в 2000-2017 г2., тысс. р./чел.

(Составлено на основе факторной модели)

\section{Baikal Research Journal}


При осуществлении государственного целевого проектного финансирования примем во внимание отрицательное воздействие на экономический рост Забайкальского края со стороны фактора «инвестиции в основной капитал», что требует дополнительных исследований в разрезе отраслей экономики, чтобы оказать правильное «влияние на управление финансовыми отношениями в разных сферах и звеньях финансовой системы” [8] и избежать стандартных ошибок, по мнению Е. А. Ермаковой, в формировании долговой политики региона [9].

Тренды Иркутской области (рис. 4) имеют положительную в 2000-2014 гг., следовательно, прогноз на 2015-2017 гг. достаточно достоверен.

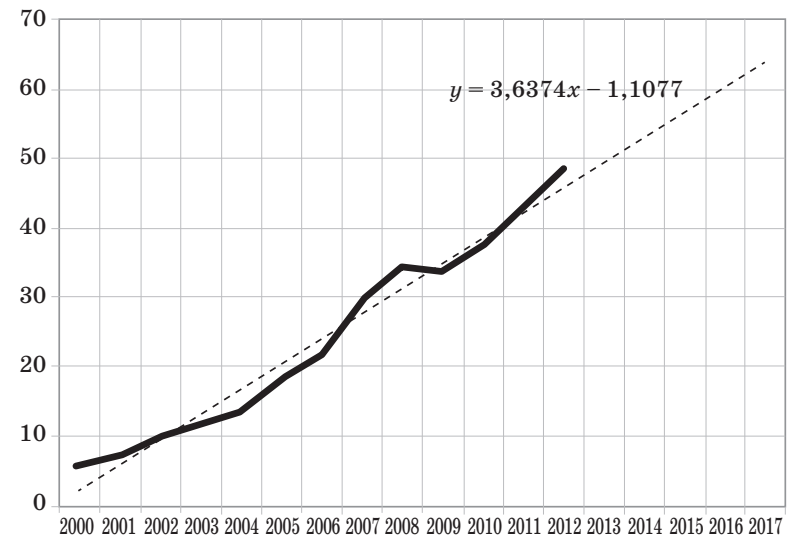

$a$

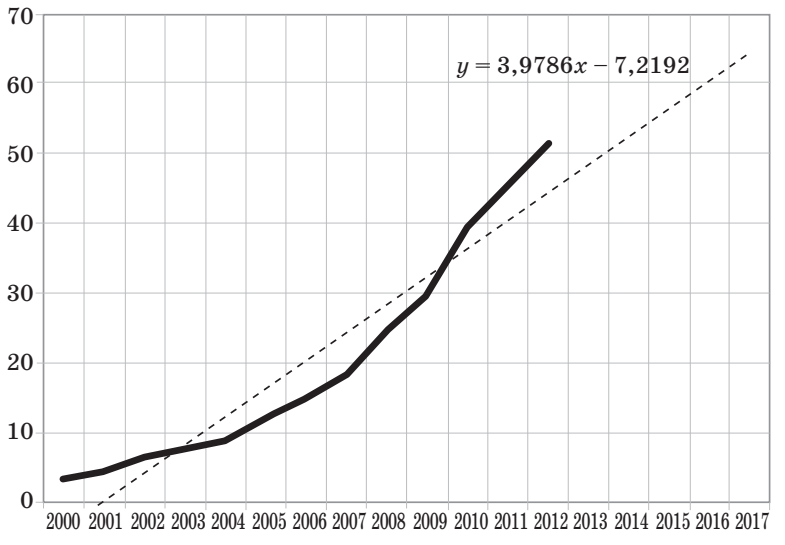

б

и государственных внебюджетных фондов (б) на душу населения

в Иркутской области в 2000-2017 г2., тыс. р./чел.

(Составлено на основе факторной модели)

Примем во внимание, что только расходы государственных внебюджетных фондов имеют положительное влияние на экономический рост данного субъекта Федерации. Отсутствие в факторной модели влияния фактора «расходы регионального бюджета» свидетельствует о разбалансированности финансовых потоков региона и об отсутствии контроля над ними со стороны региональных органов власти.

По мнению Н. М. Сабитовой, «только реальная оценка финансовых потоков в субъектах РФ может дать характеристику его финансовой устойчивости» [10]. В таких условиях финансовая поддержка со стороны федерального центра требует «механизма контроля, который должен обеспечить возможность оценки результатов реализации" [11] проектов регионального развития с учетом принципов организации бюджетной системы РФ [12]. В данном регионе следует сформировать государственно-частное партнерство, которое, как считает В. Е. Леонтьев [13], позволит эффективно осуществлять государственное финансирование проектов, в том числе инновационных, что приведет к росту ВРП.

Изучив тренды ряда факторов на 2015-2017 гг., рассмотрим, как они повлияют на рост ВРП в результате увеличения государственного целевого проектного финансирования. По мнению В. Е. Леонтьева [14], выход финансовой системы России из финансового кризиса, вызванного геополитическими конфликтами, западными санкциями и усилившейся в результате этого стагнацией в экономике, возможен только при активизации роли государства, в том числе через механизм финансово-кредитной поддержки [15].

В качестве направления осуществления государственного целевого проектного финансирования в Республике Бурятия выберем расходы государственных вне-

\section{Baikal Research Journal}


бюджетных фондов на душу населения, которые в 2014 г. составили 43,2 тыс. р. на 1 чел. Увеличение объема расходов государственных внебюджетных фондов на 13,3 тыс. p. на 1 чел. в год (до 56,5 тыс. р. на 1 чел. в год), или на 30,8 \% , будет способствовать приросту ВРП на 45,7 тыс. р. на 1 чел. в год, или на $25 \%$ (рис. 5).

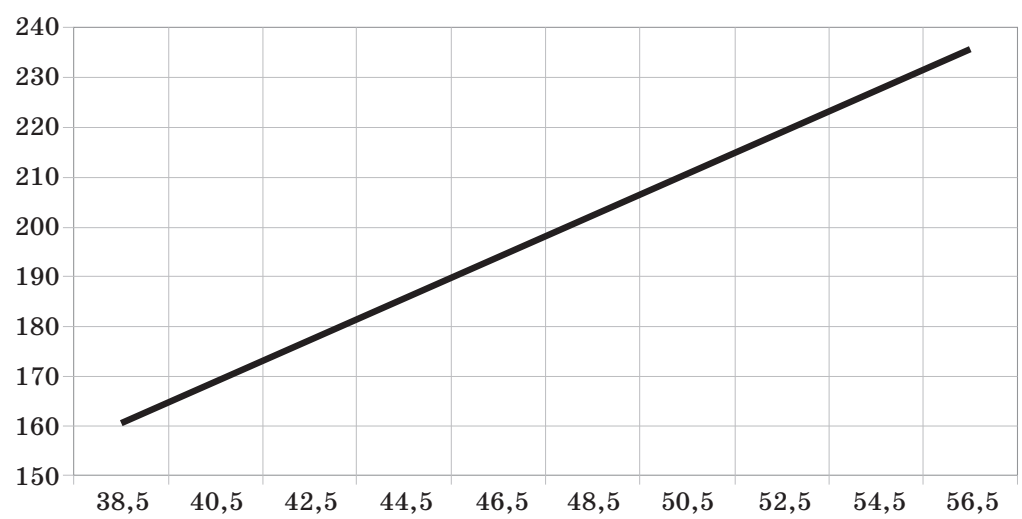

Рис. 5. Зависимость увеличения государственного финансирования расходов государственных внебюджетных фондов и валового регионального продукта в Республике Бурятия, тыс. р./чел.

(Составлено на основе факторной модели)

В качестве направления реализации государственного целевого проектного финансирования в Забайкальском крае выберем расходы консолидированного регионального бюджета на душу населения, которые в 2014 г. составили 46,6 тыс. р. на 1 чел. в год. Зависимость государственного финансирования данного фактора и ВРП показывает, что для доведения ВРП до среднероссийского необходимо увеличение данного индикатора на 7,58 тыс. р. на 1 чел. в год, или на $16,3 \%$. В Забайкальском крае в течение ряда последних лет наблюдается устойчивая динамика экономического роста при увеличении расходов консолидированного бюджета. Возможны следующие направления финансирования, нацеленные на компенсацию отрицательного влияния факторов «расходы ГВФ на душу населения» и «инвестиции в основной капитал»: формирование комфортного проживания пенсионеров, создание благоприятной бизнес-среды и льготное налогообложение юридических лиц (рис. 6).

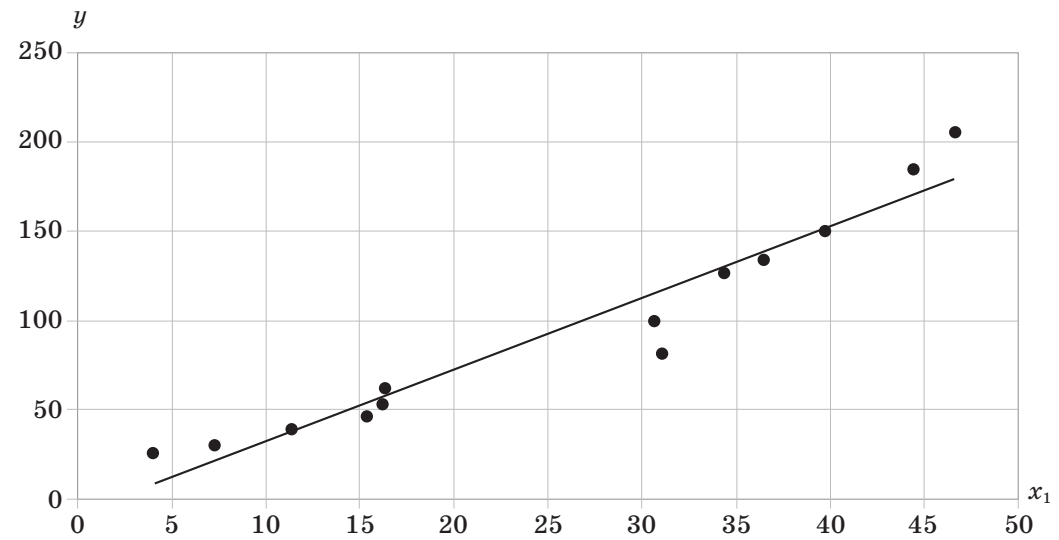

Рис. 6. Зависимость увеличения государственного финансирования расходов регионального бюджета и валового регионального продукта в Забайкальском крае, тыс. р./чел.

(Составлено на основе факторной модели)

\section{Baikal Research Journal}


В качестве направления осуществления государственного целевого проектного финансирования в Иркутской области выберем расходы государственных внебюджетных фондов на душу населения, которые в 2014 г. составили 51,2 тыс. р. на 1 чел. в год. Для доведения показателя ВРП на душу населения по Иркутской области до среднероссийского (разница составляет 27,7 тыс. р. на 1 чел.) необходимо увеличить государственное финансирование данного фактора на 7,74 тыс. р. на 1 чел. в год, или на 15,1 \% . Предлагаем следующие направления финансирования, нацеленные на компенсацию отрицательного влияния факторов «среднедушевые доходы в год» и «уровень занятости»: создание рабочих мест, формирование комфортного проживания, создание благоприятной бизнес-среды (рис. 7).

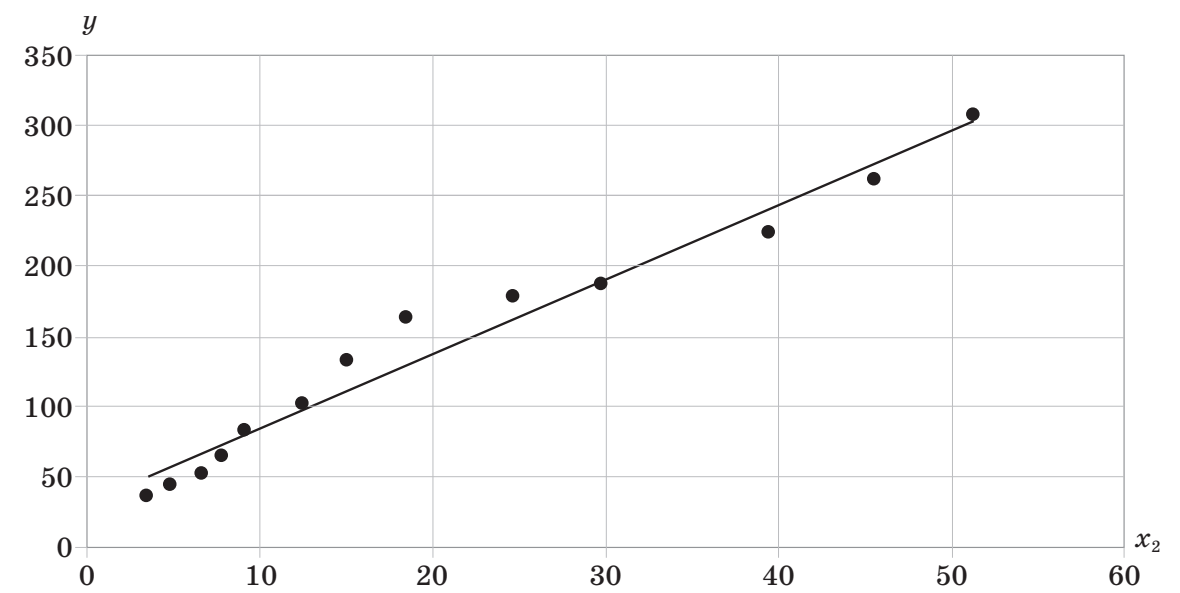

Рис. 7. Зависилость увеличения государственного финансирования расходов государственных внебюджетных фондов и ВРП в Иркутской области, тыс. $p$.чел.

(Составлено на основе факторной модели)

Проведенные расчеты позволяют сделать вывод о необходимости применения государственного целевого проектного финансирования для обеспечения экономического роста в Байкальском регионе на основе построенной модели. Это подтверждается прогнозируемым приростом ВРП в результате увеличения финансирования по предложенным направлениям.

\section{Список использованной литературы}

1. Бубнов В. А. Проблемы формирования Байкальского региона [Электронный ресурс] / В. А. Бубнов // Известия Иркутской государственной экономической академии (Байкальский государственный университет экономики и права). -2010 . - № 5. - Режим доступа: http://eizvestia.isea.ru/reader/article.aspx?id=13918.

2. Развитие производительных сил и повышение доходного потенциала Мамско-Чуйского района : монография / В. И. Самаруха, Д. Ю. Федотов, Т. В. Сорокина, В. А. Бубнов. - Иркутск, 2002. - 90 с. - Деп. в ИНИОН РАН.

3. Иванов В. В. Проблемы управления региональными финансовыми ресурсами / В. В. Иванов, А. Д. Спиваков // Финансы и кредит. - 2001. - № 10 (82). - С. 13-16.

4. Иванов В. В. Использование механизмов управления региональными финансовыми ресурсами / В. В. Иванов, А. Д. Спиваков // Финансы и кредит. - 2001. - № 14 (86). - С. 3-7.

5. Иванов В. В. Типология межбюджетных отношений и моделей бюджетного федерализма / В. В. Иванов // Вестник Мурманского государственного технического университета. 2010. - T. 13, № 1 . - C. 5-14.

6. Ермакова Е. А. Проблемы управления региональными бюджетными рисками / Е. А. Ермакова // Региональная экономика. Юг России. - 2013. — № 1. - С. 35-41.

\section{Baikal Research Journal}


7. Ермакова Е. А. Инвестиционный фонд РФ: основы организации и управления / Е. А. Ермакова // Финансы и кредит. - 2006. - № 20 (224). - С. 28-33.

8. Ермакова Е. А. Государственные финансы в финансовой системе России / Е. А. Ермакова // Финансы и кредит. - 2007. - № 3 (243). - С. 32-40.

9. Ермакова Е. А. Принципы формирования долговой политики региона / Е. А. Ермакова // Региональная экономика. Юг России. - 2013. - № 2. - С. 48-53.

10. Сабитова Н. М. К вопросу о финансовой устойчивости субъектов РФ / Н. М. Сабитова // Финансы и кредит. - 2005. — № 6 (174). - С. 30-32.

11. Сабитова Н. М. Организационные принципы бюджетной системы Российской Федерации / Н. М. Сабитова // Финансы и кредит. - 2013. — № 2 (530). — С. 2-7.

12. Сабитова Н. М. Совершенствование форм и методов финансовой поддержки субъектов Российской Федерации / Н. М. Сабитова // Финансы и кредит. — 2004. — № 24 (162). C. 2-10.

13. Леонтьев В. Е. Государственное финансирование инновационных проектов в России / В. Е. Леонтьев, А. В. Демин. - СПб. : С.-Петерб. гос. экон. ун-т, 2013. - 124 с.

14. Леонтьев В. Е. Российские финансово-кредитные институты: новые вызовы и возможности / В. Е. Леонтьев, Н. П. Радковская // Вестник Российской академии естественных наук. -2015 . - № 2. - С. 14-16.

15. Леонтьев В. Е. О мерах по дальнейшему развитию государственной финансово-кредитной поддержки малого и среднего бизнеса в регионе / В. Е. Леонтьев, К. В. Нецымайло // Интеллект. Инновации. Инвестиции. - 2012. — № 2. - С. 165-167.

\section{References}

1. Bubnov V. A. Problems of formation of Baikal Region. Izvestiya Irkutskoi gosudarstvennoi ekonomicheskoi akademii (Baykalskii gosudarstvennyi universitet ekonomiki i prava) = Bulletin of Irkutsk State Economics Academy (Baikal State University of Economics and Law), 2010, no. 5. Available at: http://eizvestia.isea.ru/reader/article.aspx?id=13918. (In Russian).

2. Samarukha V. I., Fedotov D. Yu., Sorokina T. V., Bubnov V. A. Razvitie proizvoditel'nykh sil i povyshenie dokhodnogo potentsiala Mamsko-Chuiskogo raiona [Developing industrial forces and increasing income potential of Mamsko-Chuysky District]. Irkutsk, 2002.90 p.

3. Ivanov V. V., Spivakov A. D. Problems of managing regional financial resources. Finansy $i$ kredit $=$ Finance and Credit, 2001, no. 10 (82), pp. 13-16. (In Russian).

4. Ivanov V. V., Spivakov A. D. Using mechanisms of regional financial resource management. Finansy $i$ kredit = Finance and Credit, 2001, no. 14 (86), pp. 3-7. (In Russian).

5. Ivanov V. V. Typology of inter-budget relations and models of budget federalism. Vestnik Murmanskogo gosudarstvennogo tekhnicheskogo universiteta $=$ Vestnik of Murmansk State Technical University, 2010, vol. 13, no. 1, pp. 5-14. (In Russian).

6. Ermakova E. A. Problems of managing regional budget risks. Regional'naya ekonomika. Yug Rossii = Regional Economy. South of Russia, 2013, no. 1, pp. 35-41. (In Russian).

7. Ermakova E. A. Investment fund of the Russian Federation: basics of organization and management. Finansy $i$ kredit = Finance and Credit, 2006, no. 20 (224), pp. 28-33. (In Russian).

8. Ermakova E. A. Governmental finance in Russia's financial system. Finansy $i$ kredit $=$ Finance and Credit, 2007, no. 3 (243), pp. 32-40. (In Russian).

9. Ermakova E. A. Principles of forming regional debt policy. Regional'naya ekonomika. Yug Rossii = Regional Economy. South of Russia, 2013, no. 2, pp. 48-53. (In Russian).

10. Sabitova N. M. On issue of financial stability of RF subjects. Finansy i kredit = Finance and Credit, 2005, no. 6 (174), pp. 30-32. (In Russian).

11. Sabitova N. M. Organizational principles of the Russian Federation budget system. Finansy $i$ kredit $=$ Finance and Credit, 2013, no. 2 (250), pp. 2-7. (In Russian).

12. Sabitova N. M. Mastering forms and methods of financial support of Russian Federation subjects. Finansy $i$ kredit = Finance and Credit, 2004, no. 24 (162), pp. 2-10. (In Russian).

13. Leontyev V. E., Demin. A. V. Gosudarstvennoe finansirovanie innovatsionnykh proektov $v$ Rossii [Governmental financing of innovative projects in Russia, Saint Petersburg State University of Economics Publ., 2013. 124 p.

14. Leontyev V. E., Radkovskaya N. P. Russian financial and credit institutions: new challenges and opportunities. Vestnik Rossiiskoi akademii estestvennykh nauk = Bulletin of Russian Academy of Natural Sciences, 2015, no. 2, pp. 14-16. (In Russian).

\section{Baikal Research Journal}


15. Leontyev V. E., Netsymailo K. V. Measures for further governmental financial and credit support for development of regional small and medium-sized business. Intellekt. Innovatsii. Investitsii $=$ Intelligence. Innovations. Investments, 2012, no. 2, pp. 165-167. (In Russian).

\section{Информация об авторе}

Бубнов Вячеслав Анатольевич - кандидат экономических наук, доцент, Иркутский государственный университет путей сообщения, 664074, г. Иркутск, ул. Чернышевского, 15, e-mail: bubnov_v@irgups.ru.

\section{Author}

Vyacheslav A. Bubnov - PhD in Economics, Associate Professor, Irkutsk State Railway Engineering University, 15 Chernyshevskogo St., 664074, Irkutsk, Russian Federation; e-mail: bubnov_v@irgups.ru.

\section{Библиографическое описание статьи}

Бубнов В. А. Прогноз экономического роста в результате применения государственного целевого проектного финансирования на примере Байкальского региона / В. А. Бубнов // Baikal Research Journal. — 2016. — T. 7, № 5. — DOI : 10.17150/2411-6262.2016.7(5).2.

\section{Reference to article}

Bubnov V. A. Forecasting of economic growth as a result of using governmental target-based project financing in terms of Baikal Region. Baikal Research Journal, 2016, vol. 7, no. 5. DOI: 10.17150/2411-6262.2016.7(5).2. (In Russian).

\section{Baikal Research Journal}

